\title{
Correlation of Honey Mesquite Response to Herbicides with Three Plant Variables and Soil Water
}

\author{
R.E. MEYER, J.D. HANSON, AND A.J. DYE
}

\begin{abstract}
Honey mesquite [Prosopis jullflora (Swartz) DC. var. glandulosa (Torr.) Cockerell] response to sprays of 2,4,5-T [(2,4,5-trichlorophenoxy) acetic acid) and picloram (4amino-3,5,6-trichloropicolinicacid) + 2,4,5-T was evaluated and correlated with maximum daily photosynthetic rate, upward movement of methylene dye, xylem preasure potential, and percent soil water. Picloram + 2,4,5-T was superior to 2,4,5-T alone for killing honey mesquite from May 15 through Auguat 4. Time of day the herbicide was applied had no significant effect on control. Maximum daily photosynthetic rate varied from 32.9 to $10.1 \mathrm{mg} \mathrm{CO}_{2} \mathrm{dm}^{-2}$ leaf area hr ${ }^{-1}$ and was highly correlated $(r=0.89$ to 0.92 ) with honey mesquite control with herbicides. Rate of upward movement of methylene blue dye in the xylem varied from 295 to $44 \mathrm{~cm} \mathrm{hr}^{-1}$. (MPa) while soll water content varied from 11.5 to $18.6 \%$. Upward movement of methylene blue dye, xylem pressure potential and percent soll water were not significantly correlated with honey mesquite control.
\end{abstract}

Honey mesquite [Prosopis juliflora (Swartz) DC. var. glandulosa (Torr.) Cockerell], a woody perennial of the Leguminosae, is adapted to a broad range of environmental conditions. It is distributed throughout much of the southwestern United States and occupies about 25 million ha of Texas rangeland (Smith and Rechenthin 1964). Honey mesquite is generally controlled by foliar sprays of 2,4,5-T [(2,4,5-trichlorophenoxy)acetic acid], picloram (4-amino-3,5,6-trichloropicolinic acid) $+2,4,5-T$, or dicamba $(3,6-$ dichloro-o-anisic acid) + 2,4,5-T; by basal treatment with diesel oil; or by mechanical treatments including bulldozing or chaining. Also, karbutilate [tert-butylcarbamic acid ester with 3( $m$-hydroxyphenyl)-1,1-dimethylurea[ and tebuthiuron \{[5-(1,1-dimethy-

\footnotetext{
The authors are plant physiologist and range scientist, Agricultural Research Service, USDA, Department of Range Science, Texas A\&M University, College Station, Texas 77843; High Plains Grassland Research Station, USDA-ARS. Cheyenne, 82001; and TA/OICD/USDA, Arlington Va. 22209.

Cooperative investigation of Agricultural Research Service, USDA, and the Texas

Agricultural Experiment Station, Texas A\&M University, College Station 77843.

Manuscript received August 10, 1981.
}

lethyl)-1,3,4-thiadiazol-2-yl]-N,N'-dimethylurea\} have shown promise as soil treatments (Meyer and Bovey 1979).

The seasonal response to herbicides is one of the major problems when chemically controlling honey mesquite. Generally, honey mesquite is most susceptible to foliar applied herbicides during May and June and is less responsive earlier and later in the growing season (Fisher et al. 1970, Meyer et al. 1972, Meyer 1977). Picloram and picloram $+2,4,5-T$ are more effective than 2,4,5-T alone in East Texas (Meyer 1977). Herbicides are most effective when new stem growth has completed elongation, the leaves are fully expanded and have turned dark green, and the stems are undergoing rapid radial enlargment. This period normally occurs between 40 to 90 days after bud break (Fisher et al. 1959). Dahl et al. (1971) found that soil temperature in the spring was an important factor affecting the response of honey mesquite to 2,4,5-T. One reason honey mesquite may be more susceptible to chemical control in the spring is that the total available carbohydrate level in the roots is lowest in May, due to a partial drain of food reserves for stem, leaf, and floral production and radial enlargment of stems and roots (Fisher et al. 1959, Robison et al. 1970, Wilson et al. 1975).

Dye and Hanson (1978), Hanson et al. (1978), and Hanson and Dye (1980) have reported on net photosynthetic rates $\left(P_{n}\right)$ and xylem pressure potentials of field populations of honey mesquite. No work has been done, however, that correlates the response of honey mesquite to chemical control directly with photosynthetic rates. The purpose of this study, therefore, was to correlate the response of honey mesquite to herbicides with maximum daily net photosynthetic rate and various other plant and environmental variables.

\section{Methods and Materials}

\section{Experimental Site and Plot Layout}

A site near Bryan, Texas, with a dense stand of honey mesquite 1.2 to $2 \mathrm{~m}$ tall was selected for study. Most plants had 2 to 4 stems which had emerged from the base of the plant. The area was an upland site with a 1 to $3 \%$ slope. The soil was a Wilson clay loam (a 
Table 1. Influence of 2 herbicides applied at 6 dates in 1978 on canopy reduction and mortality of honey mesquite near Bryan, Texas.

\begin{tabular}{|c|c|c|c|c|}
\hline \multirow[b]{3}{*}{ Date of application } & \multicolumn{4}{|c|}{ Honey mesquite control' } \\
\hline & \multicolumn{2}{|c|}{ Canopy reduction } & \multicolumn{2}{|c|}{ Mortality } \\
\hline & $\begin{array}{c}2,4,5-\mathrm{T} \\
(\%)\end{array}$ & $\begin{array}{c}\text { Picloram }+2,4,5-\mathrm{T} \\
(\%)\end{array}$ & $\begin{array}{c}2,4,5-T \\
(\%)\end{array}$ & $\begin{array}{c}\text { Picloram }+2,4,5-\mathrm{T} \\
(5)\end{array}$ \\
\hline $\begin{array}{l}\text { May } 15 \\
\text { May } 26 \\
\text { June } 16 \\
\text { July } 14 \\
\text { August } 4 \\
\text { October } 3 \\
\text { Mean }\end{array}$ & $\begin{array}{l}88 \mathrm{~d} \\
93 \mathrm{bcd} \\
95 \mathrm{abc} \\
91 \mathrm{~cd} \\
91 \mathrm{~cd} \\
18 \mathrm{f} \\
79 \mathrm{~s}\end{array}$ & $\begin{array}{c}99 \mathrm{ab} \\
99 \mathrm{ab} \\
100 \mathrm{a} \\
98 \mathrm{ab} \\
98 \mathrm{ab} \\
43 \mathrm{e} \\
90 \mathrm{t}\end{array}$ & $\begin{array}{l}41 \mathrm{e} \\
62 \mathrm{~cd} \\
70 \mathrm{bc} \\
52 \mathrm{de} \\
58 \mathrm{~cd} \\
0 \mathrm{f} \\
47 \mathrm{x}\end{array}$ & $\begin{array}{r}94 \mathrm{a} \\
96 \mathrm{a} \\
98 \mathrm{a} \\
90 \mathrm{a} \\
91 \mathrm{a} \\
6 \mathrm{f} \\
79 \mathrm{y}\end{array}$ \\
\hline
\end{tabular}

' Values for canopy reduction or mortality for dates or means followed by the same letter are not significantly different at the $5 \%$ level using the Duncan multiple range test. Picloram + 2,4,5-T was applied at the rate of $0.56+0.56 \mathrm{~kg} \mathrm{ha}^{-1}$ while $2,4,5-\mathrm{T}$ was applied at $1.12 \mathrm{~kg} \mathrm{ha}^{-1}$. Control ratings were made June 18,1979 .

member of fine, montmorillonitic, thermic Vertic Ochraqualfs). Four replicates of 5 plants each were used for each of 2 herbicide treatments at 4 periods of the day during each of 6 dates in 1978. A randomized block design was used; date of treatment, herbicide, and time of day for herbicide application were arranged as a factorial.

\section{Herbicide Rates and Application Method}

Herbicide treatments included the triisopropanolamine salt of picloram + the propylene glycol butyl ether ester of 2,4,5-T at 0.56+ $0.56 \mathrm{~kg} \mathrm{ha}^{-1}$ and the propylene glycol butyl ether ester of $2,4,5-\mathrm{T}$ alone at $1.12 \mathrm{ha}^{-1}$. The herbicides were applied in water at a spray volume of 187 liters $\mathrm{ha}^{-1}$ at $0600,0900,1200$, and $1800 \mathrm{hr}$ CST with a hand-carried, air, 3 nozzle boom sprayer on 6 dates. Visual ratings of percent reduction, i.e., the percentage of stem tissue killed, and percent dead plants (mortality) were made June 18, 1979 , the year following treatment.

\section{Plant Characteristics}

Rate of upward movement of methylene blue dye was determined in $\mathbf{2 0}$ trees at each date as an indicator of rate of transpiration. A $0.1 \%(w / v)$ aqueous methylene blue dye solution was infused into the stem xylem from a blood transfusion bottle equipped with a No. 16 hypodermic needle. The needle was inserted under the bark of each tree between 0930 and 1000 CST and removed $30 \mathrm{~min}$ later. The bark was stripped off progressively upward above the infusion point to the end of the dye streak; then length of the streak was measured and adjusted to $\mathrm{cm} \mathrm{hr}^{-1}$

A pressure equilibration chamber was used to determine (1 hr before sunrise) xylem pressure potential (Waring and Cleary 1967). The general procedure outlined by Haas and Dodd (1972) was followed. Pressure readings were taken on petioles of 4 leaves on different branches of the sample tree before dawn on each date of herbicide application. The leaf was removed from the tree and sealed in a pressure chamber with the excised petiole surface protruding. The basipetal end of the petiole was not allowed to extend more than $3 \mathrm{~mm}$ from the chamber lid to reduce error (Millar and Hansen 1975). The pressure in the chamber was systematically increased at a rate of $0.07 \mathrm{MPa} \mathrm{sec}-1$ as suggested by Waring and Cleary (1967).

A portable, open carbon dioxide exchange system for measuring $P_{n}$ on branches of woody plants was developed by Balding et al. (1973) and Dye and Hanson (1978). The system consisted of an assimilation chamber, a ventilation and temperature control unit, a measurement and recording unit, and a power supply unit. The components allowed continuous measurement of $\mathbf{P}_{\mathbf{n}} \cdot \mathbf{P}_{\mathrm{n}}$, in units of $\mathrm{mg} \mathrm{CO} \mathrm{cm}^{-2}$ leaf area $\mathrm{sec}^{-1}$, was calculated from the relation.

$$
P_{n}=k F \Delta \mathrm{CO}_{2} A^{-1}
$$

where $\mathrm{\Delta CO}$ was the carbon dioxide deficit within the chamber in ppm, $F$ was the flow rate of air over the branch measured as liters $\mathrm{hr}^{-1}$, and $A$ was the leaf area (one side) in $\mathrm{m}^{2}$. The constant $\mathrm{k}$ was equal to $1.79 \times 10^{-3} \mathrm{mg} \mathrm{ppm}{ }^{-1} \operatorname{liter}^{-1}$ at $25^{\circ} \mathrm{C}$ and $0.1 \mathrm{MPa}$. A photoelectric planimeter was used to estimate leaf areas (Kemph 1976). Photosynthetic rates were measured for entire diurnal cycles so maximum $P_{n}$ could be determined for each date.

\section{Soll Water Content}

Percent soil water was determined gravimetrically at depths of 0 to 30,31 to 61 , and 62 to $91 \mathrm{~cm}$ on each day of spraying. Five cores were dug with a screw-type auger (Flynt et al. 1971) on each date.

\section{Results and Discussion}

\section{Response to Herbicides}

Picloram $+2,4,5-\mathrm{T}$ was superior to $2,4,5-\mathrm{T}$ alone for honey mesquite control (Table 1). Picloram $+2,4,5-\mathrm{T}$ was more effective at reducing canopy cover than 2,4,5-T on May 15 and in July, August, and October. Picloram $+2,4,5-\mathrm{T}$ killed more honey mesquite than 2,4,5-T alone at all dates except October 3 when neither herbicide treatment was effective. Contrary to most other studies, both herbicide treatments were effective at killing honey mesquite in July and August. Generally, honey mesquite control using herbicides diminishes after early July.

Differences among times of day the herbicides were applied to

Table 2. Maximum photosynthetic rate, soll water content, rate of upward movement of methylene blue dye in the xylem, and predawn xylem pressure potential of honey mesquite on 6 dates in 1978 .

\begin{tabular}{|c|c|c|c|c|}
\hline Date & $\begin{array}{l}\text { Maximum photosynthesis } \\
\left(\mathrm{mg} \mathrm{dm}^{-2} \mathrm{hr}^{-1}\right)\end{array}$ & $\begin{array}{c}\text { Soil water content }{ }^{2} \\
(\%)\end{array}$ & $\begin{array}{l}\text { Dye movement } \\
\left(\mathrm{cm} \mathrm{hr}^{-1}\right)\end{array}$ & $\begin{array}{c}\text { Xylem pressure potential } \\
\text { (MPa) }\end{array}$ \\
\hline $\begin{array}{l}\text { May } 15 \\
\text { May } 26 \\
\text { June } 16 \\
\text { July } 17 \\
\text { August 4 } \\
\text { October 3 }\end{array}$ & $\begin{array}{l}26.9 \\
24.0 \\
32.9 \\
28.9 \\
24.4 \\
10.1\end{array}$ & $\begin{array}{l}11.9 \mathrm{~b} \\
18.6 \mathrm{a} \\
18.0 \mathrm{a} \\
11.8 \mathrm{~b} \\
11.5 \mathrm{~b} \\
17.8 \mathrm{a}\end{array}$ & $\begin{array}{l}295 \mathrm{a} \\
200 \mathrm{~b} \\
147 \mathrm{bc} \\
117 \mathrm{~cd} \\
88 \mathrm{de} \\
44 \mathrm{e}\end{array}$ & $\begin{array}{l}-0.48 \mathrm{a} \\
-0.67 \mathrm{~b} \\
-0.17 \mathrm{~b} \\
-1.01 \mathrm{c} \\
-0.89 \mathrm{c} \\
-0.65 \mathrm{~b}\end{array}$ \\
\hline
\end{tabular}

IValues within a column followed by the same letter are not significantly different at the $5 \%$ level using the Duncan multiple range test.

2Mean of 0 to 91 depth.

${ }^{3}$ Mean of 4 leaves on a tree measured predawn. 
Table 3. Correlation coeficients for plant and environmental variables versus canopy reduction and mortality of honey mesquite using 2 herbicide treatments.

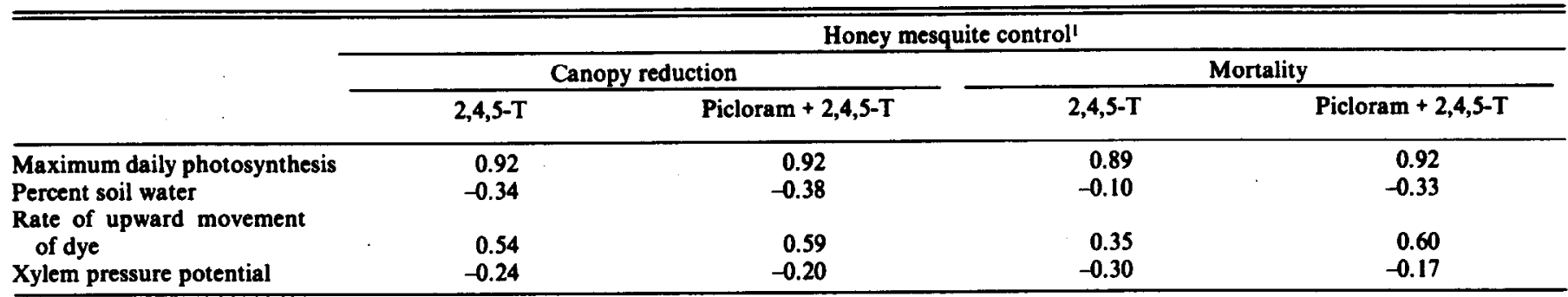

iCorrelation coefficients of 0.70 and 0.90 are needed to show significance at the $5 \%$ and $1 \%$ level, respectively.

honey mesquite were not significant (data not shown). The means for all dates varied from 78 to $81 \%$ canopy reduction and from 44 to $51 \%$ dead plants for $2,4,5-\mathrm{T}$ and 87 to $91 \%$ canopy reduction and 77 to $82 \%$ dead plants for picloram $+2,4,5-T$. These results were different from those of Bovey et al. (1972), who showed that a picloram $+2,4,5-\mathrm{T}$ mixture was slightly more effective at $1800 \mathrm{hr}$ at $0.25+0.25 \mathrm{~kg} \mathrm{ha}^{-1}$ on huisache [ Acacia farnesiana (L)Willd.] and $0.56+0.56 \mathrm{~kg} \mathrm{ha}^{-1}$ on Macartney rose than at 0600 or $1330 \mathrm{hr}$.

\section{Correlation of Plant and Soil Variables and Control}

Data collected for the plant and environmental variables are given in Table 2. Maximum net photosynthetic rate ranged from 32.9 to $10.1 \mathrm{mg} \mathrm{dm}^{-1} \mathrm{hr}^{-1}$ on June 16 and October 3, respectively. No significant differences occurred in soil water content among the 3 depths sampled; therefore, the data were pooled for use in subsequent analyses. Upward movement of methylene blue dye steadily decreased from 295 to $44 \mathrm{~cm} \mathrm{hr}^{-1}$ throughout the sampling period. Xylem pressure potential varied from -1.01 to $-0.48 \mathrm{MPa}$.

Neither soil water content nor predawn xylem pressure potential were significantly correlated with chemically induced canopy reduction (\%) or mortality of honey mesquite (Table 3 ) whereas Meyer (1977) found both significantly correlated. Soil moisture and xylem pressure potential have been shown to be very important factors influencing plant growth (Haas and Dodd 1972) and net photosynthesis (Hanson and Dye 1980). Although soil and plant moisture levels are related to plant activity and transpiration, they were less correlated with herbicide activity than photosynthesis. Apparently the herbicides used in this study enter the plants through the leaves and travel to sites of activity with the photosynthates.

Rate of dye movement within the xylem tissue of honey mesquite showed a trend to be more closely correlated to canopy reduction and mortality than soil water or xylem pressure potential (Table 3). Dye movement is a measure of the rate of xylem transport and is regulated by stomatal activity; therefore, it, in part, reflects total plant activity.

Maximum photosynthetic rate had the highest and only significant correlation with canopy reduction and mortality of sprayed honey mesquite (Table 3). These data show that maximum net photosynthetic rate is an important factor regulating honey mesquite susceptiblity to chemical control, especially if the herbicides are translocated with the photosynthate. Thus, maximum photosynthetic rate could be very useful in predicting the results of herbicide applications if a simple means of estimating photosynthesis can be developed.

\section{Literature Cited}

Balding, F.R., G.L. Cunningham, and R.F. Plummer. 1973. An inexpenive self-contained system for field measurements of gas exchange. Photosynthetica 7:382-386.

Bovey, R.W., R.H. Hau, and R.E. Meyer. 1972. Daily and seasonal response of huisache and Macartney rose to herbicides. Weed Sci. 20:577-580.

Dahl, B.E., R.B. Wadley, M.R. George, and J.L. Talbot. 1971. Influence of site on mesquite mortality from 2,4,5-T. J. Range Manage. 24:210-215.

Dye, A.J., and J.D. Hanson. 1978. Photosynthetic rates of honey mesquite in semiarid grasslands, p. 411-413. In: D.N. Hyder (ed.) First Internat. Rangeland Congr., Proc.

Flaher, C.E., C.H. Meadors, Richard Behrens, E.D. Robleon, P.T. Marion, and H.L. Morton. 1959. Control of mesquite on grazing lands. Texas Agr. Exp. Sta. Bull. 935.

Fisher, C.E., E.D. Robison, G.O. Hofiman, C.H. Meadors, and B.T. Crows. 1970. Aerial application of chemicals for control of brush on rangelands, p. 5-11. In: Tex. Agr. Exp. Sta. Prog. Rep. 2801.

Flynt, T.O., T.E. Riley, R.W. Bovey, and R.E. Meyer. 1971. Auger soil sampler for herbicide residues. Weed Sci. 19:583-584.

Hass, R.H., and J.D. Dodd. 1972. Water stress patterns in honey mesquite. Ecology 53:674-680.

Henson, J.D., A.J. Dye, and R.H. Hans. 1978. Xylem pressure potential and gas exchange phenomena of honey mesquite, p. 419-421. In: D.N. Hyder (ed.) First Intern. Rangeland Congr., Proc.

Hanaon, J.D., and A.J. Dye. 1980. Diurnal and seasonal patterns of photosynthesis of honey mesquite. Photosynthetic 14:1-7.

Kemph, P.J. 1976. Measuring fibrous roots with a leaf area meter. J. Range Manage. 29:85-86.

Meyer, R.E. 1977. Seasonal response of honey mesquite to herbicides. Texas Agr. Exp. Sta. Bull. 1174.

Meyer, R.E., and R.W. Bovey. 1979. Control of honey mesquite (Prosopis juliflora var. glandulosa) and Macartney rose (Rosa bracteata) with soil-applied herbicides. Weed Sci. 27:280-284.

Meyer, R.E., R.W. Bovey. W.T. McKelvy, and T.E. Riley. 1972. Influence of plant growth stage and environmental factors on the response of honey mesquite to herbicides. Texas Agr. Exp. Sta. Bull. 1127.

Millar, B.D., and G.K. Hansen. 1975. Exclusion errors in pressure chamber estimates of leaf water potential. Ann. Bot. 39:915-920.

Robison, E.D., R.E. Meyor, B.T. Crose, and H.L. Morton. 1970. Influence of preconditioning defoliations on honey mesquite control, p. 31-34. In: Texas Agr. Exp. Sta. Prog. Rep. 2808.

Smith, H.N., and C.A. Rechenthin. 1964. Grassland Restoration. Part 1.The Texas brush problem. USDA, Soil Conserv. Serv, 4-18114. 40 p.

Waring, R.H., and B.D. Cleary. 1967. Plant moisture stress: evaluation by pressure bomb. Science 155:1252-1254.

Wilson, R.T., B.E. Dahl, and D.R. Krię. 1975. Carbohydrate concentration honey mesquite roots in relations to phenological development and reproductive condition. J. Range Manage. 28:286-289. 